\title{
Bookreview
}

\section{G. KAULE}

\section{ARTEN UNI BIOTOPSCHUTZ}

UTB Grosse Roihe, Verlag E. Ulmer, Stuttgart, 1986; 461 pp., 74 figs. and cartograms, 54 photographs, 143 tabs., Price DM 88.-

In addition to the main author 13 others contributed to tho book. The contents cover a broader field than tho title suggests: Species and Biotopes Conservation.

The buok is divided into ten chapters and ends with the literature cited (p. 442-454) and a subject index (p. 455-461).

The first chepter (p. 13-47) is a general introduction. It discusses species and biotopes protection, as well as goneral principles of duture conservation. It deals with databases, models prospects etc. Most examples are naturally from the territory of BRD.

Chapters 2 (p. 50-126), 3 (p. 127-165) and $4(166-187)$ describe ecosystems from natural (Chapter 2) to anthropogenous (Chapter 4). The most comprehensive is Chapter Two, dealing with nutural formations (woodlands, various wetlands etc.). Chapter Four deals with such ecosystems as fiolds, quarries, damps, refuse tips etc.

Chapter Five (p. 188-247) discusses plant and animal conservation, and deals with the Red books and causes of species extinction. The most important factors are the degradation and deterioration of (water and terrestrial) biotopes.

The rather comprehensive Chapter Six (p. 248-352) evaluates various aspects (ecological and socio-ecological) of the protection of species, and communities; landscepe planning is briefly discussed, too. The whole of Chapter Soven (p. 353-382) is devoted to this problem. It gives information about the organization and legislative rules of nature conservation in different coun. tries (e.g. Switzerland, Liechtenstein, Austria and BRD).

The last three chapters are very short. They concern anthropic and anthropogenous influence on the landscape (Chapter 8: 383-393), planning (Chapter 9: 394-421) and the management of species and biotopes (Chapter 10:422-444).

The book discusses the subject of biotopes and species conservation with a broad scopo. Chapters are hoterogeneous, and sometimes overlap, which can be considered a shorteorning.

From our point of view inadequate attention is paid to anthropogoneous immissions, aspecially to air-pollutants.

The book is to be recomended not only to all conservationists, but also to ocologists, specialists in landscape-planning and to administrative workers.

It is attractive for Czech readers because it reflects a situation characteristic for a large aroa of Central Europe.

Věroslav SAMEK 